\title{
Answering Damarin's Call: How iOS Apps Approach Diversity, Equity, and Multiculturalism
}

\author{
Todd Cherner \\ Portland State University \\ U. S. A.
Alex Fegely
Coastal Carolina University
U. S. A.

\begin{abstract}
In 1998, Suzanne Damarin put forward a call for technologists and multicultural educators to work together to create technologies that promote inclusiveness and equity for students. As significant technological advancements have happened along with major changes in educational policy over the past 20 years, this study set out to examine if Damarin's call has been answered. In this article, the researchers first explain how they systematically identified a group of iOS applications designed for iPads and analyzed them for their design quality and content through a lens of diversity, equity, and multiculturalism. They then share their findings and offer implications before concluding with a response regarding the status of Damarin's call.
\end{abstract}

KEYWORDS: diversity, equity, multicultural, iOS app, iPad

Banks' Approaches to Multicultural Curriculum Reform as a Framework
The Growth of Edtech in Schools
Methodology
Findings
Implications
Conclusion
Note
References
Author Contact
Appendix A
Appendix B

The rapid development of educational technology (edtech) has impacted how lessons are taught, content is engaged, and students are assessed. Ranging from applications, websites, and programs to tablets, laptops, and smartphones, edtech is a tool for teaching and learning that provides teachers and students with 
access to vast amounts of information and the ability to complete tasks with unprecedented efficiency.

Though it is far from being an instructional panacea - as issues pertaining to access, privacy, and safety exist (Ford \& Moore, 2013; Hollandsworth, Dowdy, \& Dononvan, 2011) - students must be able to use digital technologies to solve problems, collaborate, and analyze data upon completing their compulsory education if they are to meet today's civic, academic, and professional demands (Glatthorn, Jailall, \& Jailall, 2016; Soulé \& Warrick, 2015; Van de Werfhorst, 2014). In fact, the International Society for Technology in Education's standard for Digital Citizenship states: "Students recognize the rights, responsibilities and opportunities of living, learning and working in an interconnected digital world, and they act and model in ways that are safe, legal and ethical" (Standard 2). In order to meet that standard and be fluent users of technology as citizens, learners, and professionals, students must have authentic experiences using edtech during their school years.

Blending technology into classroom instruction is a gradual process that can be fraught with practical challenges. Though school leaders should provide quality professional developments for their teachers and be prepared for skepticism about integrating edtech into the curriculum, they also must be aware of edtech's shortcomings regarding how it approaches diversity, equity, and multiculturalism (DEM) (Gorski, 2009; Voithofer \& Foley, 2002). As schools and districts continue to invest billions of dollars in edtech annually (Levy, 2016; Technology for Education Consortium, 2017) and the demographics of students continue to grow more diverse, this study's purpose is to analyze edtech designed for teaching DEM.

In 1998, Suzanne Damarin wrote a passionate article in which she questioned if multicultural educators and edtech developers could work together to improve education. Damarin (1998) was clear that, if the two parties were to be successful, the "technologist must take the lead by finding and developing uses of technology that specifically serve the needs of educators concerned with equity and multiculturalism, and thus the needs of their students" (p. 18). Ten years earlier, James A. Banks (1989) had put forward four approaches to curriculum reform-Contributions Approach, Additive Approach, Transformation Approach, and Social Action Approach-to support teachers in restructuring their lessons so that they include multiple perspectives and catalyze social change. This study adopts Banks' approaches to analyze whether Damarin's call has been answered in the last 20 years, asking:

1. What is the state - amount and quality - of iOS iPad applications designed for DEM topics?

2. What themes emerge from the iOS iPad applications identified as being developed for DEM?

To frame this study, we explain how we used Banks' approaches to multicultural curriculum reform as the basis for our analysis. We then describe the data collection and analysis procedures used, before presenting our findings and 
sharing implications. We conclude by making recommendations for future research in this area and stating whether Damarin's call has been answered.

\section{Banks' Approaches to Multicultural Curriculum Reform as a Framework}

To analyze iOS apps designed for the iPad, we adopted Banks' approaches for multicultural curriculum reform because each approach includes identifiable characteristics and features that are unique to it. Plus, as Banks, Cochran-Smith, Moll, Richert, and Zeichner (2005) explain, "Culturally responsive teachers need to know how to develop a curriculum that takes into account the understandings and perspectives of different groups while also attending to the development of higher-level cognitive skills" (p. 251). The four approaches Banks (1989) offers provide teachers with a tool they can use to analyze their method for integrating multiculturalism into their lessons; we were able to transfer them to analyze edtech used in this study.

To begin, Banks describes the Contributions Approach as the celebration of non-mainstream holidays (e.g., Cinco de Mayo, Indigenous People's Day, Hispanic Heritage Month). Within this approach, the holidays and heroes of a cultural are recognized, but that recognition is an "add-on" or supplement to the mainstream curriculum. The victimization and oppression experienced by the members of the culture is glossed over to preserve the dominant culture's narrative.

Next is the Additive Approach; teachers engage it when including specific information about a non-mainstream culture, but that culture is represented through a mainstream perspective. For example, teaching the American narrative of the pilgrims and Native Americans sharing the first Thanksgiving is additive in that it portrays a peaceful alliance between the two groups. It does not foreshadow the atrocities that would be committed to the Native Americans in the then near future. It also does not reflect current Native Americans' views on the holiday, as evidenced by the growing use of the term "Thankstaking" that refers to the taking of lives and land of Native Americans by White settlers (Salisbury, 2000).

The Transformational Approach is third. It revolves around teachers restructuring their curriculum so that it "enables students to view concepts, issues, themes, and problems from several ethnic perspectives and points of view" (Banks, 1989, p. 18). At its essence, "transformation" is reached when students deconstruct a phenomenon, large or small, and analyze how that phenomenon has impacted multiple cultures and also how those same cultures contributed to it. For example, when studying climate change in a science class, teachers can trace the groups who have released the most carbon into the atmosphere, thus contributing to climate change, and which cultures have been most impacted by climate change's adverse impacts (e.g., rising sea levels, droughts). In this activity, students would be analyzing climate change and deconstructing its causes and effects. 
Last is the Social Action Approach, which includes all the elements of the Transformational Approach along with students "taking action" in response to the phenomenon. After having studied multiple perspectives about a topic, issue, or problem, Banks (1989) suggests that students "analyze their values and beliefs, synthesize their knowledge and values, and identify alternative courses of action, and finally decide what, if any, action they will take" (p. 18). This final component of deciding to "take action" is the pinnacle of Banks' approaches. An example is students who were studying local zoning laws and found that a disproportionately large amount of space located in neighborhoods where lower-income families lived was allocated for future power plants and waste management services. In response, those students began a letter writing campaign requesting that the municipal officials rezone the community to provide for a more equitable distribution of those facilities. Together, Banks' final two approachesTransformation Approach and Social Action Approach-are methods for actualizing the equitable representation of multiple groups along with cultivating higher-order thinking skills necessary for culturally responsive teaching (Banks et al., 2005).

This study's context is rooted in the tension-filled movement to use edtech in schools during a time when student demographics are shifting worldwide. Student diversity includes multiple races and ethnicities, as well as multiple cognitive capabilities, bodily abilities, native languages, and socioeconomic statuses. As students are more receptive to curriculum materials that reflect their own diversities and voice their group's perspective (Banks, 1998), today's edtech must also be responsive to those concerns if it is to be used for learning. Thus, the current educational and sociopolitical climates provide an ideal backdrop for this study.

\section{The Growth of Edtech in Schools}

Since the advent of mobile technologies, particularly smartphones and tablets, schools are investing heavily in edtech. In 2014, for example, Nagel estimated that over $33 \%$ of students then enrolled in public schools used a smartphone, laptop, or tablet daily as part of their schoolwork. A year later, Pearson's (2015) survey of technology use in grades 4-12 during 2015 found that "78\% of elementary school students report that they regularly use a tablet...two in three middle school students $(69 \%)$ report using tablets...[and] nearly half of high school students (49\%) report using tablets" (p. 8). These data show the rise in edtech use in schools, one that we predict will continue well into the foreseeable future. In response, edtech corporations and start-ups have developed an array of products and services that are growing the edtech market.

When schools invest in edtech, they are not just purchasing devices. The products currently offered range from hardware and software to services that include consultations, professional development, case studies, and demonstrations. Schools must provide their stakeholders with both the edtech and 
the training to use it effectively in their classroom. The missing piece in this context, however, is the students who use it. Over the past decades, the United States' student body has grown more diverse racially, ethnically, and linguistically (Banks, 2015; Ryu, 2015). Furthermore, the treatment and experiences of nonheteronormative students (Dinkins \& Englert, 2015; van Leent, 2017) and emphasis on the cultural knowledge and capital of indigenous peoples (Barnhardt, 2007; McIntosh, Moniz, Craft, Golby, \& Steinwand-Deschambeault, 2014) have gained increased public attention. If edtech is to be culturally responsive, we posit that these diverse student groups must be reflected in the edtech they are using. As the edtech marketplace continues to grow, the time is ripe to examine how edtech has attended to issues of DEM in response to Damarin's call.

\section{Methodology}

This study's purpose is twofold: (a) to explore and report on the state of iOS application (apps) for the iPad designed to be instructional tools for teaching about DEM and (b) to present a mixed methods approach that can be replicated for studying the state, availability, quality, and quantity of different pieces of edtech. Whereas this study analyzed iOS apps for the iPad in relation to DEM issues, future researchers can use this methodology as a springboard for analyzing edtech related to other purposes (e.g., websites designed for literacy, software programs focused on English language acquisition, and applications created to support students with special needs).

To begin the analysis, multiple methods were used to better understand the state of iPad apps identified for DEM. We began by systematically identifying a sample using the Google search engine. Google was selected because it is "by far the most popular search engine used by more people all over the world with hundreds of millions search queries every single day" (Boswell, 2017, para. 2). In addition to its popularity, at the time of this study Google was the only search engine that offered a filter specifically for apps, which made it a premier tool for identifying them.

Before searching, we chose to collaborate with two colleagues whom we viewed as experts in diversity and education. Both experts hold advanced degrees in education with a cognate in critical studies, have published research that focuses on inequity in education, and regularly teach graduate courses related to diversity. The connection between this study and the experts' knowledge is in the analysis of curriculum materials (e.g., young adult novels, textbooks, and prepackaged reading curriculums). As these experts routinely analyze materials for DEM characteristics for their teaching and scholarship, they had significant experience locating materials using search engines. Because we intended to utilize a search engine to locate iOS apps for iPads and wished to be systematic in our approach, we valued the experience of these experts. 
To collaborate, we first described this study to these colleagues and asked them which terms they may use to identify the type of apps they sought. A discussion resulted in the specific search terms to be used. During September 2016, we entered those terms into the Google search engine and used its "apps" filter to identify apps. Table 2 shows both the search terms and number of apps identified.

Table 1. Number of Apps Found by Keyword

\begin{tabular}{cc|cc}
\hline Search Term & $\begin{array}{c}\text { Number of Apps } \\
\text { Reported }\end{array}$ & Search Term & $\begin{array}{c}\text { Number of Apps } \\
\text { Reported }\end{array}$ \\
\hline Cultural Diversity & 1 & $\begin{array}{c}\text { Inclusive } \\
\text { Technology }\end{array}$ & 2 \\
\hline Culture & 3 & Multicultural & 5 \\
\hline Diversity & 7 & $\begin{array}{c}\text { Multicultural } \\
\text { Education }\end{array}$ & 2 \\
\hline $\begin{array}{c}\text { Diversity } \\
\text { Education }\end{array}$ & 8 & Racism & 2 \\
\hline Inclusiveness & 2 & Religion Education & 2 \\
\hline Inclusion & 2 & Urban Education & 3 \\
\hline $\begin{array}{c}\text { Inclusiveness } \\
\text { Education }\end{array}$ & 2 & World Culture & 2 \\
\hline Total & & & 42 \\
\hline
\end{tabular}

To conduct the search, each term was entered individually to Google, and the name of the apps along with a link to download them from iTunes was recorded on a spreadsheet. If a term had two words, quotation marks were added around the term so that the entire term was searched together and not as two different words. For instance, when religion education was entered, it was searched as "religion education" and not as religion and education. This strategy is important because several apps contain the words religion and education in their description, but only two contain religion education together in their description. After conducting the searches, 42 apps were found. The search was further reduced to identify those apps that teachers may select to support student learning, using the following criteria:

1. The app had to be free to download to an iPad;

2. The app's content had to provide information about a topic related to DEM; and

3. The app's purpose could not be to promote an event (e.g., conference, meeting, or rally), community group, professional organization, or school.

These criteria were intentionally selected because, at the time of the data collection, iPads were still one of the most popular tablets being used in $\mathrm{K}-12$ education (Seifert, 2017; Thurrot, 2015), and teachers and students with iPads would likely be able to download free apps. In addition, the parameters were still wide enough so that iOS apps designed for the iPad by developers from different nationalities were included. At this level of data collection, the language that 
described the app was used to identify it, not the app's content or functionality. The next two criteria required that the apps include information related to DEM as a topic of study, and not as an event or group related to DEM. ${ }^{1}$ Of the apps originally identified, 16 were included in the final sample.

For the analysis, we first evaluated the quality of the apps' design, adopting the "Design" section of Lee and Cherner's (2015) comprehensive rubric for analyzing instructional apps. The overall rubric consists of 24 checks that are aligned to three sections: Instructional, Engagement, and Design. The "Instructional" section includes eight checks that evaluate an app's educational value (e.g., the app's rigor, if its content is appropriate for school, and how it provides feedback, among other criteria). The "Engagement" section includes seven checks that consider how and why students might be motivated to engage the app due to the pace at which it presents information, the amount to which students can customize the app, and how they interact with it. The "Design" section includes nine checks that analyze an app's functionality; these are shown in Appendix A. The Design section was adopted because it includes a "Cultural Sensitivity" dimension as a checkpoint for analyzing the authenticity of a cultural representation made by an app. Furthermore, the additional checks focus on the users' experience when engaging the app's content and the quality of that content. These checks work together in that they analyze how an app represents a culture and then provide an analysis of the quality for that representation, which aligns to this study's focus. Further discussion is offered in the findings section.

To evaluate their design, the apps were reviewed independently before the analyses were combined on a spreadsheet. A Pearson Correlation Coefficient for each app rating was found to help ensure the rating's reliability (Muijs, 2010), as shown in Appendix B. To evaluate the correlation's strength, Mukaka's (2012) guidelines shown in Table 3 were adopted.

Table 2. Mukaka's (2012) Guidelines for Interpreting Correlation Strength

\begin{tabular}{ccccc}
\hline $\begin{array}{c}\text { Very high } \\
\text { positive } \\
\text { correlation }\end{array}$ & $\begin{array}{c}\text { High positive } \\
\text { correlation }\end{array}$ & $\begin{array}{c}\text { Moderate } \\
\text { positive } \\
\text { correlation }\end{array}$ & $\begin{array}{c}\text { Low positive } \\
\text { correlation }\end{array}$ & $\begin{array}{c}\text { Negligible } \\
\text { correlation }\end{array}$ \\
\hline $0.90-1.00$ & $0.70-0.90$ & $0.50-0.70$ & $0.30-0.50$ & $0.00-0.30$ \\
\hline
\end{tabular}

After completing this reliability check, we met to discuss the apps' design attributes.

Next, the analysis aimed to identify patterns, trends, and themes in the apps. For this analysis, we each identified socially constructed codes (SCCs) based on the content included in each app. Davis and Pepperell (2012) explained that SCCs "are developed based on the researcher's knowledge of the field" ( $p$. 8). Brennan (2008) adds that SCCs "are used to categorize data into meaningful units" (p. 58). In our analysis, SCCs allowed us to use our understanding of both 
the data and edtech field to organize SCCs into categories, which could be used to identify patterns, trends, and themes in the apps.

As we analyzed the apps, we independently wrote small, concise phrases that described the apps' content. These phrases were inputted into separate spreadsheets as headings. As more apps were analyzed, we each added phrases about how these apps aligned to our already established headings. If a phrase was recorded that did not align with a previously made heading, it was used to create a new one. This process allowed for the phrases to be used to create headings that worked to substantiate and operationalize themselves.

Once the apps were coded individually, we met and shared SCCs and notes. Together, we then looked for trends and patterns in the data and worked to categorize them into themes. This iterative process resulted in four main themes being established and substantiated.

Though care was taken to document this study's methodology, limitations still impacted it. To begin, Google's search filter for apps is no longer available. After being online through December 2016, Google removed the filter. Researchers wishing to duplicate this study will need to develop a new protocol to identify an apps sample.

Next, the search terms used to identify the apps represent another limitation. Even being purposefully cautious in selecting search terms, other researchers may have different terms in mind that they wish to use. In this context, we argue that there are no "right" or "wrong" terms to use, as long as the method for selecting them was thoughtful. Also, the time at which the terms were entered into the Google search engine is a limitation. Varying trends, changes, and fluctuations in the data used by Google's search engine algorithm may have impacted the apps reported. In addition, as Google favors popularity of websites without regarding their content (Meric et al., 2002), Google's search engine algorithm is not responsive to issues pertaining to racism, misogynistic trends, and other prejudices. Furthermore, "Research shows that users typically use very few search terms when seeking information in a search engine and rarely use Advanced Search queries" (Noble, 2013, p. 2), and this study is no exception. Though we conducted 14 separate searches and were mindful in how the terms were entered into Google, we did not use the Advanced Search features that Noble (2013) referenced. Plus, we were based in the United States; researchers in other countries may identify different apps based on their location.

Regarding the content, care was taken to analyze it using qualitative coding procedures; however, that act itself is a limitation too. By design, qualitative coding contains limitations due to sample size and analysis methods (Castro, Kellison, Boyd, \& Kopak, 2010; Coffey \& Atkinson, 1996). In this study, we sought to build credibility by analyzing the apps using different techniques and debriefing about our independent coding before together making meaning of the collected sample (Jick, 1979; Thurmond, 2001). With these measures in place, there is still subjectivity in analyzing the data because all researchers filter the data through their own experiences, ideas, and biases during the analysis. In all, limitations were 
part of this study, but we worked to reduce their impact by fully describing and disclosing our data analysis procedures.

\section{Findings}

To share the findings, we first describe the strengths and shortcomings of the apps' design before discussing the themes found across them.

Based on our analysis of the apps' design using the "Design" dimension in Lee and Cherner's (2015) rubric, we calculated averages for the nine checks. (The complete analysis is shown in Appendix B.) Based on the averages, a noticeable distinction was found in scores regarding the apps' interface and functionality. In this context, we operationalized interface to mean the way in which the app presents content to users and functionality as the way in which users engage the app's content.

Regarding their interface, the apps all had a mean score of 4.7 or above on a five-point scale when analyzing how they organized on-screen content; how users were to engage the content; and the ways the apps synthesized images, sounds, and texts together to cohesively represent a topic. This finding demonstrates that the apps were made with the user in mind and that best multimedia and digital design principles were used to create them. Though these elements do not add meaningful multicultural content to the apps, they do enhance the beauty of the content included.

However, the same is not true for the apps' functionalities. The apps' functionality elements included three measures, with mean scores of 1.92, 3.28, and 3.5. Whereas the interface deeply analyzed the apps' aesthetics, the functionality investigated dimensions with distinctly different purposes. The "Integration" item analyzed if the apps were able to connect with other apps, websites, users' emails, and online communities. Being able to share content between platforms allows multiple users to collaborate, which is a key characteristic for $21^{\text {st }}$ century success (Dede, 2010). The apps earned an average score of 1.92 for this check, evidence of a shortcoming in this area.

Apps that automatically load the content users were last engaging when they logged off work to maximize efficiency because users will not have to spend time locating that content when they log in again. Plus, having to start engaging an app's content from the beginning each time it is loaded does not advance learning, unless review or remediation is needed. Therefore, apps that automatically load the content users were last engaging when they logged off score higher on the rubric than apps requiring users either to start at the beginning of the content or to manually select it. In all, this sample's apps averaged a 3.28, which indicates that they often allowed users to manually select the apps' content. This functionality can be viewed in two opposing ways. First, being manually able to select the content provides users an opportunity to skip foundational information necessary to build understanding of the topic being addressed by the app. On the other hand, 
this functionality allows users to bypass information they already know. Lee and Cherner (2015) value apps that feature the functionality to automatically load the content last being used, either the exact content or in proximity to it, and being able to do so earns three of five points.

When addressing topics related to DEM, it is paramount that the different cultures, peoples, and customs be represented as accurately as possible. In their rubric, Lee and Cherner (2015) rate apps highly that provide opportunities for users to connect directly with individuals from those populations. Apps that include authentic artifacts from cultures also rate higher than apps that contain general, biased, or stereotypical depictions. In all, the apps included in this study's sample averaged a 3.5 rating in this category. This finding demonstrates that the apps tended to include either an authentic or general depiction of a population and that the developers were cautious not to use degrading representations of those populations.

For the study's second focus, the apps were thematically analyzed and four main themes were identified.

\section{Apps Often Teach Diversity Through the Form of a Narrative}

The majority of this sample's apps took the narrative form. Narratives can effectively engage students by harnessing their imaginations (Conle, 2003), and experiential narratives in particular can be used to address morality issues and provide diverse perspectives (Oser, 1994; Puka, 1990). In the context of digital narratives, McShay and Gilchrist (2008) explain that they help students uncover their own racial and socio-economic identities, which can in turn impact how students come to understand diverse perspectives in their own lives (Conle, $\mathrm{Li}, \&$ Tan, 2002). The narratives identified in these apps range from being passive digital storybooks with audio narration to simple, story-based animations through fully interactive, choose-your-own-adventure style formats.

This sampling of apps approached the narrative modality in different ways: passive, active, and interactive. To start, Collins Big Cat: Around the World Story Creator, Sleepover in Antarctica, and Sleepover in Africa at Amani's Graduation employ a passive e-storybook interface. Users flip pages by swiping a finger across the screen, and the app reads the text aloud while triggering animations. Conversely, diversityDNA: Cultural Diversity Training that Sticks uses a series of educational videos with animated objects and pictures to tell a story or explain a concept. Elevator Up, Switch Fan and Sensory Room each includes a character with a handicap that users guide and employs an interactive story format that users advance by touching the screen. In I Got This: An Interactive Story, users navigate the character's life from the protagonist's perspective accompanied by a screenby-screen textual story. This app also uses a game-like interactive touch story system, so users select different objects within the context of the narrative to advance the story. For example, users touch the alarm clock to turn it off and 
vigorously tap the screen to keep the character from falling asleep. In total, eight of the apps utilized a story-like delivery strategy to engage users.

\section{Apps Are Frequently Designed to Introduce Diversity, But Rarely Address It in Detail}

This sample's apps addressed diversity; however, the ways in which they did so were superficial. The apps primarily alluded to diversity by showcasing characters or images of non-White people, such as characters representing multiple races and ethnicities, wearing garments reflective of their culture (e.g., a hijab and traditional African garb), or moving using assistance (e.g., a wheelchair and braces). Furthermore, cursory information was at times included, though the information made unclear references to multiple groups of people. While there were some instances of diversity being presented as a moral lesson, many of the apps skirted over specifically addressing diversity issues by simply acknowledging that people have unique customs and backgrounds.

First, characters of different races and ethnicities were commonly featured. Apps such as Sleepover in Africa, Sleepover in Antarctica, Collins Big Cat: Around the World, Elevator Up, Inclusion Bridges, Kids Planet Discovery - Educational Games to Learn, and I Got This all included non-White characters, but information about their culture was omitted. For example, Inclusion Bridges features non-White characters; however, the game focuses on prejudice as being a problem in certain countries. It does not offer information about the race, culture, or ethnicities that are part of the game, and this paucity of information was not unique to that app. In fact, the majority of apps often alluded to diversity through the use of non-White characters, but they did not provide authentic descriptions, images, or histories related to those characters' race or ethnicity. Yet, that is not to say that all the apps were categorized by this lack of detail.

Everyday Racism, created by Australian developers, allows users to select non-White characters that include Patrick, an Indigenous Australian; Aisha, a hijabwearing woman from Oman; and Vihaan, a college student from India. Users then experience a first-person perspective as their character goes through daily activities that include their character being subjected to prejudice and bigotry due to race, ethnicity, religion, and nationality. Depending on the chosen character, at the end of the day, the app poses "Did You Know" questions like the following:

1. "Did you know that three out of ten Australians born in the Middle East report being treated disrespectfully?"

2. "Did you know that more than one quarter of Indigenous Australians experience racism in shops or restaurants?"

3. "Did you know that racism can cause a range of health problems such as depression, anxiety, heart disease and premature birth?"

The purpose of these questions is to provide users a reflective moment after experiencing racism through their character's perspective. 
In this sample, the apps did not highlight the rich cultural history, information, or experiences of the diverse populations included in their content. In fact, Equality \& Diversity Foundation, Sleepover in Africa, Inclusion Bridges, and Stereowiped were the only apps that probed more deeply than simple imagery of the different cultures. Equality \& Diversity Foundation explains how non-White Christians may have different prayer, eating, and holiday customs. Sleepover in Africa lightly addressed female education in the local culture. Inclusion Bridges highlighted cultural problems in different countries but did not advance past simply stating the problems. Stereowiped brought to light misnomers about Muslims, Jews, and Sikhs among other groups. The other apps in this sample vaguely or superficially represented or alluded to multiculturalism in unsubstantial ways. For example, Daily Diversity in the Workplace and Equality \& Diversity Foundation, the only apps that had a business focus, omitted discussing specific aspects of diversity. Cultural information was substituted with broad statements about diversity, as exemplified by the Equality \& Diversity Foundation that stated, "Diversity is simply taken to mean human difference." The business-themed apps focused more on accepting differences than on investigating the similarities and differences between the diverse groups of people and how they can build multicultural communities.

\section{Apps Represent Multiple Populations, Though Some Populations Are Absent}

The apps included in this study span 14 different app development teams from five different countries: six apps from the United Kingdom; five apps from the United States; and one app each from Australia, Denmark, and Pakistan. In order to gain a context for these apps, the demographics of the United States, United Kingdom, and Australia-the three most diverse countries on this list-must be examined.

According to the U.S. Census Bureau (2014), the largest non-White populations in the United States are Hispanic (16.3\%), Black (12.6\%), and Asian $(4.8 \%)$, and these numbers are expected to increase. Specifically, D'Angelo and Dixey (2001) predict that by 2050, Hispanics will comprise $25 \%$ of the population in the United States, Blacks $14 \%$, and Asians $8 \%$. In the United Kingdom, where the most apps in this sample were developed, the largest non-White populations are Asian (7\%) and Blacks (3\%) (Office for National Statistics, 2013). In Australia, another majority White country, Asians also represent $7 \%$ of the non-White population with Aborigines comprising $1 \%$ (National Center for Education Statistics, 2016).

In addition, there is a mismatch between the students of color and the predominantly White, predominantly female teaching force in both the United States and the United Kingdom (Cartledge \& Kourea, 2008). Whereas students of color in the United States comprise $47 \%$ of the student population (National Center for Education Statistics, 2016), only $17 \%$ of the teachers are of color (Feistritzer, 
2011). In addition to recruiting more teachers of color, culturally responsive instructional materials can be used to welcome students' identities and create inclusive environments (Banks, 1998; Brown, 2007; Richards, Brown, \& Forde, 2007). Based on this study's findings, apps are not responding to this need.

When looking across this sampling of apps for diverse groups, Figure 1 shows the nine categories these apps used to represent diverse population.

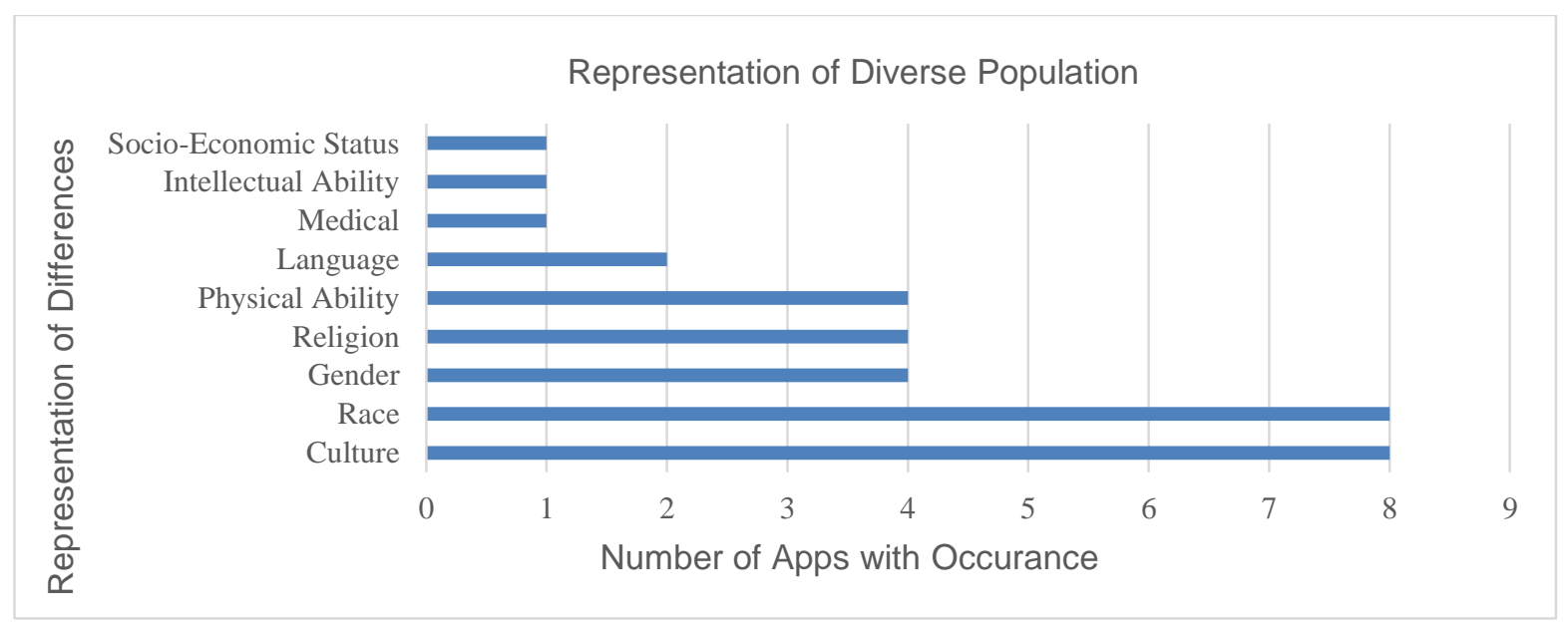

Figure 1. Representation of diverse populations in the app sample

Although multiple groups were represented, some were excluded. For example, as many as 6.4 million indigenous people- 5.2 million Native Americans and 1.2 million Native Hawaiian and Pacific Islanders-identify as Americans having indigenous roots (U.S. Census Bureau, 2014). However, none of the Americandeveloped apps included these populations. Only Everyday Racism, which was developed in Australia, included any indigenous characters. The connection is that over half a million people in Australia identify as having indigenous ancestry largely being either Aborigines $(400,000)$ (Siasoco, n.d.) or Pacific Islanders $(166,272)$ (Pryke, 2014) —and the app developers were being responsive to those populations. Medical diversity, represented by a character with diabetes; intellectual diversity, represented by a character who has autism; and socioeconomic diversity, represented by an image and blurb about homeless populations, were groups represented, if only slightly, in this sample.

Religious groups and sexual minorities were also underrepresented. Jews were only mentioned in one app. Muslims and Hindus were mentioned in two apps. The lesbian, gay, bisexual, and transgender communities went unrepresented in this sample, with none of the apps offering specific information on sexuality or gender identity. 


\section{Apps Typically Compare White to Non-White Cultures}

The apps often come from the perspective of White culture and frequently neglect comparing and contrasting other cultures from around the world. The term "White Culture" includes not only skin color, but also "shared common cultural traits, such as language, religion, and dress" (Sadker, Sadker, \& Zittleman, 2008, p. 68). Furthermore, Matias, Viesca, Garrison-Wade, Tandon, and Galindo (2014) explain that Whiteness is not necessarily only for the white-skinned, as it is "a social construction that embraces white culture, ideology, racialization, expressions and experiences, epistemologies, emotions and behaviors" (p. 290). These apps predominantly focused on contrasting White culture with non-White culture. In Sleepover in Africa, Sleepover in Antarctica, and Collins Big Cat Around the World, the apps' main characters leave America to visit other parts of the world. Once at their destinations, the characters experience cultures different from Westernized White culture. In Daily Diversity in the Workplace, the app provides tips for attracting non-White people for jobs, and it warns to avoid posting job advertisements in co-workers' networks as a safeguard against homogenous work environments forming. In addition, Daily Diversity in the Workplace cautions that non-White people of similar qualifications can be judged differently because of a name, picture, or dialect.

Because White culture is the predominant default culture in the sampling of apps, the educational insights such as cultural, historical, and experiential common ground that can be gleaned by comparing two non-White cultures with each other is lost. Hispanics and Blacks are the United States' largest minority groups, and they are contrasted only to White culture in these apps. Although characters depicting Black culture were featured in some apps, there was no analysis, juxtaposition, discussion, or evaluation of two minority cultures.

\section{Implications}

Using Banks' dimensions as a frame, it is clear that few, if any, of the apps reach the Transformation or Social Action approaches. To begin, students as well as teachers may bring preconceived notions about race with them into the classroom, which can block open dialogue. Discussing diversity can be difficult due to students feeling uncomfortable with confronting their own prejudices, judgments, and guilt (Trosset, 1998), which makes it easier to add or celebrate a culture rather than examining the social issues impacting that culture from multiple perspectives (Banks, 1989). App developers have an opportunity to create edtech that can highlight these social issues and their impact. As the majority of the apps in this study introduced diversity topics or exposed students to different groups of people, they were addressing multiculturalism via the Additive Approach. Though Banks (1989) recognizes that the Additive Approach "can be the first phase in a more radical curriculum" (p. 17), it cannot be the last approach. App developers 
can support the deeper integration of DEM into the curriculum by creating characters and including topics in the apps that reflect the diverse students learning from them. Teachers can then use those apps as opportunities to engage their students in "courageous" conversations (Maxwell, Locke, \& Scheurich, 2013) about social issues and actions they can take in response.

Furthermore, DEM apps for education are predominantly aimed toward child-aged audiences. The apps' reading level, kid-themed cartoon characters, and storybook deliveries are geared toward elementary to middle school-aged children. This format and style aligns to the Additive Approach because, though the apps may bring DEM content into the curriculum, the topics and activities in the apps are still centered on mainstream, Euro-centric ideas and ideologies. Indepth analysis of DEM issues along with racial and cultural histories go unaddressed deeply until the secondary level. The finding that apps rarely go into substantial depth about the social issues could be attributed to the apps being designed for younger students. However, the business-centric apps also failed to go into detail about DEM issues and did not address any underlying issues. Rather, it appeared that they emphasized best practices that were safe for "dealing" with diversity in the workplace. As such, these apps too do not include any approach more advanced than being additive.

The White versus non-White cultural contrast found in this study's apps may stem from the development teams' countries of origin, and that contrast too lends itself to the Additive Approach. Predominantly White countries with White cultures created all but one of the apps in the data set, and that may further explain the embeddedness of Euro-centric cultural markers in the apps. As Damarin (1998) expressed, "Technologies themselves and the vision of an electronic community are largely the products and dreams of privileged White men" (p. 12) propagating White culture. Though the intent of app developers may not be to create a White bias, society has a "dysconscious racism" as King (1991) explains, or a subconscious thought process that tacitly acquiesces to White culture by "accepting the existing order of things as given" (p. 134-5). As Memmi (1965) outlines, contemporary society is one of two groups, the colonizers (Whites in this context) and the colonized people (non-Whites). Through colonization, a system Whites used to "Europeanize them [non-Whites], to make radical changes to their traditional ways of knowing the world and knowing themselves, and adopt, as if their own, the cognitive universe of the colonizer" (Lombardi, 2012, p. 16), White culture has spread around the globe and become popular culture (Memmi, 1965). By becoming popular culture, Euro-centric norms and values have immersed themselves into the curriculum materials and edtech designated for DEM, which inhibits them with respect to breaking into the Transformation and Action Approaches.

Previously, non-digital resources (e.g., textbooks, bulletin boards, and novels) were relied upon to reflect the different cultures and ethnicities of diverse student populations equitably (Brown, 2007; Richards, Brown, \& Forde, 2007). As apps grow in popularity, the onus has shifted to developers to address issues of DEM in the products they create. App developers ignoring the responsibility for 
incorporating diverse representations and information into their products can be harmful. When instructional tools marginalize students' cultural identities, a disconnect leading to self-esteem issues, conflict, rejection, underachievement, or withdrawal from school can occur (Brown, 2007; Irvine, 1992; Richards et al., 2007). Banks' (1989) four approaches provide app developers a framework for analyzing the type of content and activities that need to be included if their apps are to attend to DEM issues while promoting a transformational approach.

\section{Conclusion}

This article used its research questions to determine the status of Damarin's (1998) call for technologists to take the lead in forging a relationship with multicultural educational stakeholders. The question 20 years later then becomes, "Has that call been met?" Before answering that question, we wish to share recommendations that app developers can use to advance apps identifying as DEM to Banks' Transformational and Action approaches.

First, the technology now exists to support person-to-person interaction. Though genuine references, artifacts, and images can portray a culture authentically, personal interaction has benefits that cannot be replicated. Developers can create methods for students to interact directly with members of different cultures within their apps. With the popularization of virtual reality and video conferencing, among other technologies, those types of interactions are now very possible, and apps can use those functionalities so that students can have authentic learning experiences. For example, an app could be developed that highlights social issues, and students from around the globe can share their perspectives about it. In this way, the app would be using a transformation approach because students from multiple cultures are sharing perspectives and ideas about a social issue.

Second, developers can move past addressing DEM topics mostly in narrative form. Narrative does have appeal and benefits to younger students, but the modality can be inherently limiting and bereft of substantial explanation or analysis for older students. One idea for creating these experiences is for apps first to present information about a DEM topic and then have a follow-up activity for students that requires them to use Web 2.0 tools to research it in their local context. The app can then provide an avenue for publicly sharing that work. By making their research visible, the app would be employing an action approach because students are working to inform the public of information they identified related to the DEM topic.

Third, app developers can work to be more inclusive regarding the diverse individuals depicted in their apps. For example, though there was some racial, ethnic, and bodily diversity included in the apps, multiple groups of people were not included. Being inclusive of sexual minorities and native populations, among several other groups, would make the apps more welcoming. In order to keep pace 
with classrooms' ever-evolving student makeups, more culturally responsive and representative images and characters are needed. This representation would add multiple perspectives to the apps that connect well with Banks' Transformation Approach, and it would better reflect the students who would be engaging these digital materials for learning. Plus, as textbooks fade to the background, app developers inherit publishers' moral responsibility to represent peoples of all types within their materials.

With edtech being used in schools more widely and student populations growing more diverse, quality digital materials teachers can use that promote inclusiveness are needed now more than ever. Given the burgeoning edtech marketplace, we strongly encourage educators to be outspoken and make the need for apps that honor DEM issues apparent to developers. Developers have an opportunity to meet that need, and though some apps for DEM issues do exist, too many of them contain only "additive" features and functionalities to allow us to say that Damarin's (1998) call has been met. Now is the time for app developers to take the lead.

\section{Note}

1. The National Association of Multicultural Education (NAME) has an application designed for iOS devices that focuses only on promoting and providing information about its conference. Though NAME's app was one connected to the Multicultural keyword, it did not provide teachers with content they may have students engage to build their understanding of DEM topics and was subsequently eliminated.

\section{References}

Banks, J. A. (2015). Cultural diversity and education. New York, NY: Routledge.

Banks, J., Cochran-Smith, M., Moll, L., Richert, A., \& Zeichner, K. (2005). Teaching diverse learners. In L. Darling-Hammond \& J. Bransford (Eds.), Preparing teachers for a changing world (pp. 232-276). San Francisco, CA: JosseyBass.

Barnhardt, R. (2007). Creating a place of Indigenous knowledge in education: The Alaska Native Knowledge Network. In D. A. Gruenewald \& G. A. Smith (Eds.), Place based education in a global age: Local diversity (pp. 113133). New York, NY: Taylor and Francis Group.

Brennan, M. (2008). Mourning and disaster: Finding meaning in the mourning for Hillsborough and Diana. Newcastle, UK: Cambridge Scholars Publishing.

Brown, M. (2007). Educating all students: Creating culturally responsive teachers, classrooms, and schools. Intervention in School and Clinic 43(1), 57-62. 
Boswell, W. (2017). What is the most popular search engine? Lifewire. Retrieved from https://www. lifewire.com/most-popular-search-engines-3482117

Cartledge, G., \& Kourea, L. (2008). Culturally responsive classrooms for culturally diverse students with and at risk for disabilities. Exceptional Children, 74(3), 351-371.

Castro, F. G., Kellison, J. G., Boyd, S. J., \& Kopak, A. (2010). A methodology for conducting integrative mixed methods research and data analyses. Journal of Mixed Methods Research, 4(4), 342-360.

Coffey, A., \& Atkinson, P. (1996). Making sense of qualitative data: Complementary research strategies. Thousand Oaks, CA: Sage Publications.

Collins Big Cat: Around the World Story Creator. (2011). HarperCollins Publishers Ltd (Version 1.0). [Mobile application software]. Retrieved from https://itunes.apple.com/us/app/collins-big-cat-around-the-world-storycreator/id485306015? $\mathrm{mt}=8$

Conle, C. (2003). An anatomy of narrative curricula. Educational Researcher, 32(3), 3-15.

Conle, C., Li, X., \& Tan, J. (2002). Connecting vicarious experience to practice. Curriculum Inquiry, 32(4), 429-452.

D'angelo, A. M., \& Dixey, B. P. (2001). Using multicultural resources for teachers to combat racial prejudice in the classroom. Early Childhood Education Journal, 29(2), 83-87.

Damarin, S. K. (1998). Technology and multicultural education: The question of convergence. Theory into Practice, 37(1), 11-19.

Davis, C. A., \& Pepperell, J. L. (2012). My sister, our stories: Exploring the lived experience of school leavers through narrative and poetics. The Qualitative Report, 17(29), 1-25.

Dede, C. (2010). Comparing frameworks for 21 st century skills. In J. Bellanca \& R. Brandt (Eds.), 21st century skills (pp. 51-76). Bloomington, IN: Solution Tree Press.

Dinkins, E. G., \& Englert, P. (2015). LGBTQ literature in middle school classrooms: Possibilities for challenging heteronormative environments. Sex Education, 15(4), 392-405.

diversityDNA: Cultural Diversity Training that Sticks. (2016). Mobile roadie (Version 5.6.2). [Mobile application software]. Retrieved from https://itunes.apple.com/us/app/diversitydna-cultural-diversity-training-thatsticks/id382146609? $\mathrm{mt}=8$

Elevator Up. (2015). Inclusive Technology Ltd (Version 1.0). [Mobile application software]. Retrieved from https://itunes.apple.com/us/app/elevatorup/id1048649385?mt=8 
Equality \& Diversity Foundation. e-Learning WMB (Version 2.8). [Mobile application software]. Retrieved from https://itunes.apple.com/gb/ app/equality-diversity-foundation/id778461260? $\mathrm{mt}=8$

Everyday Racism. (2015). All Together Now (Version 1.5.1). [Mobile application software]. Retrieved from https://itunes.apple.com/us/app/everydayracism/id726683275? $\mathrm{mt}=8$

Feistritzer, E. (2011). Profiles of teachers in the U.S. 2011. Washington, DC: National Center for Education Information.

Ford, D. Y., \& Moore III, J. L. (2013). Understanding and reversing underachievement, low achievement, and achievement gaps among highability African American males in urban school contexts. The Urban Review, 45(4), 399-415.

Glatthorn, A. A., Jailall, J. M., \& Jailall, J. K. (2016). The principal as curriculum leader: Shaping what is taught and tested. Thousand Oaks, CA: Corwin Press.

Gorski, P. C. (2009). Insisting on digital equity: Reframing the dominant discourse on multicultural education and technology. Urban Education, 44(3), 348364.

Hollandsworth, R., Dowdy, L., \& Donovan, J. (2011). Digital citizenship in K-12: It takes a village. TechTrends, 55(4), 37-47.

iAdvocate. (2011). Syracuse University (Version 1.0). [Mobile application software]. Retrieved from https://itunes.apple.com/us/app/iadvocate/ id427814325mt=8

I Got This. An Interactive Story. (2015). The Lawrence Hall of Science (Version 2.0). [Mobile application software]. Retrieved from https://itunes.apple.com/ us/app/i-got-this-an-interactive-story/id995079699?mt=8

Inclusion Bridges. (2016). X-Lives Interactive S.L. (Version 1.0.2). [Mobile application software]. Retrieved from https://itunes.apple.com/us/app/ inclusion-bridges/id1128101696? $\mathrm{mt}=8$

International Society for Technology in Education. (2016). ISTE standards for students (Standard No. 2). Retrieved from https://www.iste.org/ standards/for-students

Irvine, J. (1992). Making teacher education culturally responsive. In M.E. Bilworth (Ed.), Diversity in teacher education: New expectations (p. 79-82). San Francisco, CA; Jossey-Bass.

Jick, T. D. (1979). Mixing qualitative and quantitative methods: Triangulation in action. Administrative Science Quarterly, 24(4), 602-611.

Kids Planet Discovery - Educational Games to Learn. (2016). Planet Factory Interactive (Version 3.9). [Mobile application software]. Retrieved from https://itunes.apple.com/us/app/kids-planet-discovery-educational-gamesto-learn/id533055109? $\mathrm{mt}=8$ 
King, J. (1991). Dysconscious racism: Ideology, identity, and miseducation of teachers. Journal of Negro Education, 60(2), 133-146.

Lee, C., \& Cherner, T. (2015). A comprehensive evaluation rubric for assessing instructional apps. Journal of Information Technology Education, 14, 21-53.

Levy, H. O. (2016). How should schools purchase ed. tech? Education Week. Retrieved from http://www.edweek.org/ew/articles/2016/04/13/how-shouldschools-purchase-ed-tech.html

Lombardi, M. (2012). Immortalizing the spirit of the colonizer. CUNY Academic Works. Retrieved from http://academicworks.cuny.edu/cc_etds_theses/136

Matias, C. E., Viesca, K. M., Garrison-Wade, D. F., Tandon, M., \& Galindo, R. (2014). "What is critical whiteness doing in OUR nice field like Critical Race Theory?" Applying CRT and CWS to understand the White imaginations of White teacher candidates. Equity \& Excellence in Education, 47(3), 289304.

Maxwell, G. M., Locke, L. A., \& Scheurich, J. J. (2013). Case study of three rural Texas superintendents as equity oriented change agents. The Qualitative Report, 18(11), 1-23.

Mclntosh, K., Moniz, C., Craft, C. B., Golby, R., \& Steinwand-Deschambeault, T. (2014). Implementing school-wide positive behavioural interventions and supports to better meet the needs of indigenous students. Canadian Journal of School Psychology, 29(3), 236-257.

McShay, J., \& Gilchrist Fath, J. (2008). Discovering identity through digital stories. Society for Information Technology \& Teacher Education International Conference, 2008, (1), 936-939.

Memmi, A. (1965). The Colonizer and the colonized. Boston, MA: Beacon Press.

Meric, F., Bernstam, E. V., Mirza, N. Q., Hunt, K. K., Ames, F. C., Ross, M. I., Kuerer, H. M., ... \& Singletary, S. E. (2002). Breast cancer on the world wide web: Cross sectional survey of quality of information and popularity of websites. Bmj, 324(7337), 577-581.

Muijs, D. (2010). Doing quantitative research in education with SPSS. Washington DC: Sage.

Mukaka, M.M. (2012). A guide to appropriate use of correlation coefficient in medical research. Malawi Medical Journal, 24(3), 69-71.

Nagel, D. (2014). One-third of U.S. students use school-issued mobile devices. Technology Horizons in Education Journal. Retrieved from https://thejournal.com/articles/2014/04/08/a-third-of-secondary-studentsuse-school-issued-mobile-devices.aspx

National Center for Education Statistics. (2016, May). The condition of education participation in education - elementary/secondary - racial/ethnic enrollment in public schools - indicator May (2016). Retrieved from https://nces.ed.gov/programs/coe/indicator_cge.asp 
Noble, S. U. (2013). Google search: Hyper-visibility as a means of rendering Black women and girls invisible. InVisible Culture, 19, 1-23.

Office for National Statistics. (2013). 2011 Census: Key statistics and quick statistics for local authorities in the United Kingdom. Retrieved from http://webarchive.nationalarchives.gov.uk/20160105160709/http://www.on s.gov.uk/ons/rel/census/2011-census/key-statistics-and-quick-statisticsfor-local-authorities-in-the-united-kingdom---part-1/rft-ks201uk.xls

Oser, F. (1994). Moral perspective on teaching. Review of Research in Education, 20, 57-127.

Pearson, LTD. (2015). Student mobile device survey 2015. Retrieved from http://www.pearsoned.com/wp-content/uploads/2015-Pearson-StudentMobile-Device-Survey-Grades-4-12.pdf

Pryke, J. (2014, August 28). Pacific Islanders in Australia: Where are the Melanesians? Retrieved from http://devpolicy.org/pacific-islanders-inaustralia-where-are-the-melanesians-20140828/

Puka, B. (1990). Be your own hero. Careers in commitment. Troy, NY: Rensselaer Polytechnic Institute.

Richards, H., Brown, A., \& Forde, T. (2007). Addressing diversity in schools: Culturally responsive pedagogy. Council for Exceptional Children. 64-68.

Ryu, M. (2015). Positionings of racial, ethnic, and linguistic minority students in high school biology class: Implications for science education in diverse classrooms. Journal of Research in Science Teaching, 52(3), 347-370.

Sadker, D. M., Sadker, M. P., \& Zittleman, K. R. (2008). Teachers, schools, and society (8th ed). New York, NY; McGraw Hill.

Salisbury, R. (2000). Rainbows of stone. Tucson, AZ: University of Arizona Press.

Seifert, D. (2017, January). Samsung's new Chromebooks are Google's answer to the iPad Pro and Surface Pro. The Verge. Retrieved from http://www.theverge.com/ces/2017/1/4/14167978/samsung-chromebookplus-pro-google-stylus-ces-2017

Sensory Room. (2014). Inclusive Technology Ltd (Version 1.0). [Mobile application software]. Retrieved from https://itunes.apple.com/us/app/sensoryroom/id814529452? mt=8

Siasoco, R. V. (n.d.). Aboriginal Australia. Retrieved from http://www.infoplease.com/spot/aboriginal1.html

Sleepover in Africa at Amani's Graduation. (2013). Forty Winks, LLC (Version 1.0). [Mobile application software]. Retrieved from https://itunes.apple.com/us/ app/sleepover-in-africa-at-amanis-graduation/id782928443? $\mathrm{mt}=8$ 
Sleepover in Antarctica. (2013). Forty Winks, LLC (Version 1.0). [Mobile application software]. Retrieved from https://itunes.apple.com/us/app/ sleepover-in-antarctica/id763862367? mt=8

Soulé, H., \& Warrick, T. (2015). Defining 21st century readiness for all students: What we know and how to get there. Psychology of Aesthetics, Creativity, and the Arts, 9(2), 178-186.

Stereowiped. (2015). Ess Cee (Version 2.0). [Mobile application software]. Retrieved from https://itunes.apple.com/us/app/stereowiped/id972396140? $\mathrm{mt}=8$

Switch Fan. (2015). Inclusive Technology Ltd (Version 1.0). [Mobile application software]. Retrieved from https://itunes.apple.com/us/app/switch-fan/ id 1048650844 ? $\mathrm{mt}=8$

Technology for Education Consortium. (2017). How school districts can save (billions) on edtech. New York, NY: Author.

Thurmond, V. A. (2001). The point of triangulation. Journal of Nursing Scholarship, 33(3), 253-258.

Thurrot, P. (2015, August). Chromebooks passes iPad, gains on Windows in US education market. Petri IT Knowledgebase. Retrieved from https://www.petri.com/chromebooks-passes-ipad-gains-on-windows-in-useducation-market

Trosset, C. (1998). Obstacles to open discussion and critical thinking: The Grinnell College study. Change: The Magazine of Higher Learning, 30(5), 44-49.

United States Census Bureau. (2014, January 31). Profile of general population and housing characteristics: 2010 demographic profile data. Retrieved from https://factfinder.census.gov/faces/tableservices/jsf/pages/productview.xht $\mathrm{ml}$ ?pid=DEC_10_DP_DPDP1\&prodType=table

Van de Werfhorst, H. G. (2014). Changing societies and four tasks of schooling: Challenges for strongly differentiated educational systems. International Review of Education, 60(1), 123-144.

Van Leent, L. (2017). Supporting school teachers: Primary teachers' conceptions of their responses to diverse sexualities. Sex Education, 4, 440-453.

Voithofer, R., \& Foley, A. (2002). Post-IT: Putting postmodern perspectives to use in instructional technology-A response to Solomon's "Toward a PostModern Agenda in Instructional Technology." Educational Technology Research and Development, 50(1), 5-14 


\section{Author Contact}

Todd Cherner: tcherner@pdx.edu

Portland State University, Graduate School of Education, Curriculum and Instruction, 1900 SW 4th Ave \#200, Portland OR, 97207

Alex Fegely afegely@coastal.edu

Instructional Technology, 100 Tom Trout Drive, Prince Building 215, Conway, SC 29526

\section{Appendix A}

\section{Comprehensive Evaluation Rubric for Instructional Apps}

(From the "Design" Section of Lee and Cherner, 2015)

\section{B. Design: The following dimensions are used to evaluate an app's overall functionality.}

B1: Ability to Save Progress: Does the app allow users to return to the content they were last engaging after exiting the app?

\begin{tabular}{|c|c|c|c|c|c|}
\hline 5 & 4 & 3 & 2 & 1 & NA \\
\hline $\begin{array}{l}\text { After exiting } \\
\text { an app, users } \\
\text { can reopen } \\
\text { the app and } \\
\text { automatically } \\
\text { return to the } \\
\text { content they } \\
\text { were last } \\
\text { engaging } \\
\text { when they } \\
\text { logged off. }\end{array}$ & $\begin{array}{l}\text { After exiting } \\
\text { an app, users } \\
\text { can reopen } \\
\text { the app and } \\
\text { resume } \\
\text { engaging it } \\
\text { automatically } \\
\text { in close } \\
\text { proximity to } \\
\text { where they } \\
\text { were when } \\
\text { they logged } \\
\text { off. }\end{array}$ & $\begin{array}{l}\text { After exiting } \\
\text { an app, users } \\
\text { can reopen } \\
\text { the app and } \\
\text { manually } \\
\text { select the } \\
\text { content they } \\
\text { were last } \\
\text { engaging } \\
\text { when they } \\
\text { logged off. }\end{array}$ & $\begin{array}{l}\text { After exiting } \\
\text { an app, users } \\
\text { can reopen it } \\
\text { and manually } \\
\text { select the } \\
\text { content they } \\
\text { were last } \\
\text { engaging } \\
\text { when they } \\
\text { logged off, } \\
\text { but the } \\
\text { content may } \\
\text { be different. }\end{array}$ & $\begin{array}{l}\text { After exiting } \\
\text { an app, } \\
\text { users must } \\
\text { begin on the } \\
\text { first level } \\
\text { when } \\
\text { returning to } \\
\text { the app. }\end{array}$ & $\begin{array}{l}\text { Not } \\
\text { Appli } \\
\text { cable }\end{array}$ \\
\hline \multicolumn{6}{|c|}{$\begin{array}{l}\text { B2. Integration: Is the app enhanced by how it connects to (1) other apps, (2) online } \\
\text { communities, (3) independent websites, and (4) users' email? }\end{array}$} \\
\hline 5 & 4 & 3 & 2 & 1 & NA \\
\hline $\begin{array}{l}\text { The app is } \\
\text { enhanced } \\
\text { with how it } \\
\text { integrates } \\
\text { with all four } \\
\text { of the listed } \\
\text { connections. }\end{array}$ & $\begin{array}{l}\text { The app is } \\
\text { enhanced } \\
\text { with how it } \\
\text { integrates } \\
\text { with three of } \\
\text { the listed } \\
\text { connections. }\end{array}$ & $\begin{array}{l}\text { The app is } \\
\text { enhanced } \\
\text { with how it } \\
\text { integrates } \\
\text { with two of } \\
\text { the listed } \\
\text { connections. }\end{array}$ & $\begin{array}{l}\text { The app is } \\
\text { enhanced } \\
\text { with how it } \\
\text { integrates } \\
\text { with only one } \\
\text { of the listed } \\
\text { connections. }\end{array}$ & $\begin{array}{l}\text { The app } \\
\text { does not } \\
\text { integrate } \\
\text { with any of } \\
\text { the listed } \\
\text { connections. }\end{array}$ & $\begin{array}{l}\text { Not } \\
\text { Appli } \\
\text { cable }\end{array}$ \\
\hline
\end{tabular}




\begin{tabular}{|c|c|c|c|c|c|}
\hline 5 & 4 & 3 & 2 & 1 & NA \\
\hline $\begin{array}{l}\text { The app's } \\
\text { text, } \\
\text { graphics, } \\
\text { videos, } \\
\text { sound, and } \\
\text { speech are } \\
\text { always } \\
\text { organized in } \\
\text { a way that } \\
\text { enhances the } \\
\text { app's } \\
\text { content. }\end{array}$ & $\begin{array}{l}\text { The app's } \\
\text { text, } \\
\text { graphics, } \\
\text { videos, } \\
\text { sound, and } \\
\text { speech are } \\
\text { usually } \\
\text { organized in } \\
\text { a way that } \\
\text { complements } \\
\text { the app's } \\
\text { content. }\end{array}$ & $\begin{array}{l}\text { The app's } \\
\text { text, } \\
\text { graphics, } \\
\text { videos, } \\
\text { sound, and } \\
\text { speech are } \\
\text { organized in } \\
\text { a way that } \\
\text { does not } \\
\text { enhance or } \\
\text { detract from } \\
\text { the app's } \\
\text { content. }\end{array}$ & $\begin{array}{l}\text { The app's } \\
\text { text, } \\
\text { graphics, } \\
\text { videos, } \\
\text { sound, and } \\
\text { speech are } \\
\text { not well } \\
\text { organized } \\
\text { and may } \\
\text { detract from } \\
\text { the app's } \\
\text { content. }\end{array}$ & $\begin{array}{l}\text { The app's } \\
\text { text, } \\
\text { graphics, } \\
\text { videos, } \\
\text { sound, and } \\
\text { speech are } \\
\text { cluttered } \\
\text { and } \\
\text { confusing, } \\
\text { which } \\
\text { detracts } \\
\text { from the } \\
\text { app's } \\
\text { content. }\end{array}$ & $\begin{array}{l}\text { Not } \\
\text { Appli } \\
\text { cable }\end{array}$ \\
\hline
\end{tabular}

B4. Ease of Use: Is the app intuitive and are users able to engage it with minimal guidance?

\begin{tabular}{|l|l|l|l|l|l|}
\hline \multicolumn{1}{|c|}{5} & \multicolumn{1}{|c|}{4} & \multicolumn{1}{c|}{3} & \multicolumn{1}{c|}{2} & \multicolumn{1}{c|}{ NA } \\
\hline $\begin{array}{l}\text { Users are } \\
\text { able to } \\
\text { engage the } \\
\text { app } \\
\text { immediately } \\
\text { with no } \\
\text { guidance. }\end{array}$ & $\begin{array}{l}\text { Users are } \\
\text { able to } \\
\text { engage the } \\
\text { app } \\
\text { immediately } \\
\text { with minimal } \\
\text { guidance. }\end{array}$ & $\begin{array}{l}\text { Users are } \\
\text { able to } \\
\text { engage the } \\
\text { app, but only } \\
\text { after some } \\
\text { guidance. }\end{array}$ & $\begin{array}{l}\text { Users are } \\
\text { able to } \\
\text { engage the } \\
\text { app, but only } \\
\text { after } \\
\text { substantial } \\
\text { guidance. }\end{array}$ & $\begin{array}{l}\text { Users are } \\
\text { able to } \\
\text { engage the } \\
\text { app, but } \\
\text { training } \\
\text { materials } \\
\text { are } \\
\text { continually } \\
\text { needed to } \\
\text { do so. }\end{array}$ & $\begin{array}{l}\text { Not } \\
\text { Appli } \\
\text { cable }\end{array}$ \\
\end{tabular}

B5. Navigation: How easily can users move through the app's content and options?

\begin{tabular}{|c|c|c|c|c|c|}
\hline 5 & 4 & 3 & 2 & 1 & NA \\
\hline $\begin{array}{l}\text { Users can } \\
\text { move through } \\
\text { the app's } \\
\text { content and } \\
\text { options } \\
\text { fluidly. }\end{array}$ & $\begin{array}{l}\text { Users need } \\
\text { to put forth } \\
\text { some effort to } \\
\text { move through } \\
\text { the app's } \\
\text { content and } \\
\text { options. }\end{array}$ & $\begin{array}{l}\text { Users need } \\
\text { to make } \\
\text { multiple } \\
\text { clicks and/or } \\
\text { swipes to } \\
\text { move through } \\
\text { the app's } \\
\text { content and } \\
\text { options. }\end{array}$ & $\begin{array}{l}\text { Users are } \\
\text { somewhat } \\
\text { impeded from } \\
\text { moving fluidly } \\
\text { through the } \\
\text { app's content } \\
\text { and options } \\
\text { because of } \\
\text { its } \\
\text { organization. }\end{array}$ & $\begin{array}{l}\text { Users } \\
\text { encounter } \\
\text { substantial } \\
\text { challenges } \\
\text { when trying } \\
\text { to move } \\
\text { through the } \\
\text { app's } \\
\text { content and } \\
\text { options } \\
\text { because of } \\
\text { its disjointed } \\
\text { organization. }\end{array}$ & $\begin{array}{l}\text { Not } \\
\text { Appli } \\
\text { cable }\end{array}$ \\
\hline
\end{tabular}


B6. Goal Orientation: Does each component of the app contribute to users learning the intended objective?

\begin{tabular}{|c|c|c|c|c|c|}
\hline 5 & 4 & 3 & 2 & 1 & NA \\
\hline $\begin{array}{l}\text { All } \\
\text { components } \\
\text { of the app } \\
\text { contribute to } \\
\text { users } \\
\text { learning the } \\
\text { objective. }\end{array}$ & $\begin{array}{l}\text { Most } \\
\text { components } \\
\text { of the app } \\
\text { contribute to } \\
\text { users } \\
\text { learning the } \\
\text { objective. }\end{array}$ & $\begin{array}{l}\text { Some } \\
\text { components } \\
\text { of the app } \\
\text { contribute to } \\
\text { users } \\
\text { learning the } \\
\text { objective. }\end{array}$ & $\begin{array}{l}\text { Few } \\
\text { components } \\
\text { of the app } \\
\text { contribute to } \\
\text { users } \\
\text { learning the } \\
\text { objective. }\end{array}$ & $\begin{array}{l}\text { None of the } \\
\text { app's } \\
\text { components } \\
\text { contribute to } \\
\text { users } \\
\text { learning the } \\
\text { objective. }\end{array}$ & $\begin{array}{l}\text { Not } \\
\text { Appli } \\
\text { cable }\end{array}$ \\
\hline
\end{tabular}

B7. Information Presentation: Is the app's content presented in a logical manner? (e.g. the app's content grows increasingly rigorous as users experience success, the app activates users' background knowledge before presenting them new information, and/or the app provides an overview of its content before users engage specific tutorials or activities.)

\begin{tabular}{|c|c|c|c|c|c|}
\hline 5 & 4 & 3 & 2 & 1 & NA \\
\hline $\begin{array}{l}\text { The app's } \\
\text { content is } \\
\text { presented in } \\
\text { a logical } \\
\text { manner. }\end{array}$ & $\begin{array}{l}\text { The app's } \\
\text { content is } \\
\text { presented in } \\
\text { a manner } \\
\text { that is mostly } \\
\text { logical. }\end{array}$ & $\begin{array}{l}\text { The app's } \\
\text { content is } \\
\text { presented in } \\
\text { a manner } \\
\text { that is } \\
\text { somewhat } \\
\text { logical. }\end{array}$ & $\begin{array}{l}\text { The app's } \\
\text { content is } \\
\text { presented in } \\
\text { a manner } \\
\text { that is } \\
\text { somewhat } \\
\text { illogical. }\end{array}$ & $\begin{array}{l}\text { The app's } \\
\text { content is } \\
\text { presented in } \\
\text { an illogical } \\
\text { manner. }\end{array}$ & $\begin{array}{l}\text { Not } \\
\text { Appli } \\
\text { cable }\end{array}$ \\
\hline
\end{tabular}

B8. Media Integration: Are the app's texts, graphics, videos, sounds, and speech integrated effectively so each of the app's media components complements each other and forms a cohesive program?

\begin{tabular}{|c|c|c|c|c|c|}
\hline 5 & 4 & 3 & 2 & 1 & NA \\
\hline $\begin{array}{l}\text { The app's } \\
\text { text, } \\
\text { graphics, } \\
\text { videos, } \\
\text { sounds, and } \\
\text { speech are } \\
\text { integrated } \\
\text { seamlessly to } \\
\text { form a } \\
\text { cohesive } \\
\text { program. }\end{array}$ & $\begin{array}{l}\text { The app's } \\
\text { text, } \\
\text { graphics, } \\
\text { videos, } \\
\text { sounds, and } \\
\text { speech are } \\
\text { integrated } \\
\text { adequately to } \\
\text { form a } \\
\text { cohesive } \\
\text { program. }\end{array}$ & $\begin{array}{l}\text { The app's } \\
\text { text, } \\
\text { graphics, } \\
\text { videos, } \\
\text { sounds, and } \\
\text { speech are } \\
\text { integrated } \\
\text { poorly, but } \\
\text { they still form } \\
\text { a mostly } \\
\text { cohesive } \\
\text { program. }\end{array}$ & $\begin{array}{l}\text { The app's } \\
\text { text, } \\
\text { graphics, } \\
\text { videos, } \\
\text { sound, and } \\
\text { speech are } \\
\text { mismatched } \\
\text { to the app's } \\
\text { content, but } \\
\text { they still form } \\
\text { a somewhat } \\
\text { cohesive } \\
\text { program. }\end{array}$ & $\begin{array}{l}\text { The app's } \\
\text { text, } \\
\text { graphics, } \\
\text { videos, } \\
\text { sound, and } \\
\text { speech are } \\
\text { mismatched } \\
\text { to the app's } \\
\text { content, and } \\
\text { it does not } \\
\text { form a } \\
\text { cohesive } \\
\text { program. }\end{array}$ & $\begin{array}{l}\text { Not } \\
\text { Appli } \\
\text { cable }\end{array}$ \\
\hline
\end{tabular}


B9. Cultural Sensitivity: Does the app use culturally responsive teaching methods to represent diverse populations?

\begin{tabular}{|c|c|c|c|c|c|}
\hline 5 & 4 & 3 & 2 & 1 & NA \\
\hline $\begin{array}{l}\text { The app } \\
\text { allows users } \\
\text { to connect to } \\
\text { and share } \\
\text { ideas with } \\
\text { people from } \\
\text { diverse } \\
\text { communities } \\
\text { across the } \\
\text { globe. }\end{array}$ & $\begin{array}{l}\text { The app } \\
\text { allows users } \\
\text { to explore } \\
\text { diverse } \\
\text { cultures from } \\
\text { across the } \\
\text { globe using } \\
\text { authentic } \\
\text { pictures, } \\
\text { images, } \\
\text { and/or texts. }\end{array}$ & $\begin{array}{l}\text { The app } \\
\text { makes } \\
\text { general } \\
\text { references to } \\
\text { one or more } \\
\text { cultures. }\end{array}$ & $\begin{array}{l}\text { The app } \\
\text { makes } \\
\text { reference to } \\
\text { diverse } \\
\text { cultures, but } \\
\text { the } \\
\text { information } \\
\text { contains } \\
\text { some cultural } \\
\text { biases. }\end{array}$ & $\begin{array}{l}\text { The app } \\
\text { presents } \\
\text { stereotypical } \\
\text { images and } \\
\text { information } \\
\text { about } \\
\text { cultures. }\end{array}$ & $\begin{array}{l}\text { Not } \\
\text { Appli } \\
\text { cable }\end{array}$ \\
\hline
\end{tabular}

\section{Appendix B}

\section{Researchers' Analysis of Sample Apps Based on Their Design}

\begin{tabular}{|c|c|c|c|c|c|c|c|c|c|c|}
\hline Dimension & \multicolumn{2}{|c|}{$\begin{array}{l}\text { Diversity } \\
\text { DNA }\end{array}$} & \multicolumn{2}{|c|}{$\begin{array}{l}\text { I Got } \\
\text { This }\end{array}$} & \multicolumn{2}{|c|}{$\begin{array}{c}\text { Daily } \\
\text { Diversity... } \\
\text { Workplace }\end{array}$} & \multicolumn{2}{|c|}{$\begin{array}{c}\text { Equality \& } \\
\text { Diversity } \\
\text { Foundation }\end{array}$} & \multicolumn{2}{|c|}{ iAdvocate } \\
\hline $\begin{array}{l}\text { B1. Ability to } \\
\text { Save } \\
\text { Progress }\end{array}$ & 4 & 4 & 5 & 1 & 5 & 4 & 5 & 4 & 5 & 4 \\
\hline B2. Integration & 5 & 4 & 1 & 1 & 2 & 1 & 1 & 1 & 2 & 2 \\
\hline $\begin{array}{l}\text { B3. Screen } \\
\text { Design }\end{array}$ & 5 & 3 & 5 & 3 & 5 & 4 & 5 & 4 & 5 & 5 \\
\hline $\begin{array}{l}\text { B4. Ease of } \\
\text { Use }\end{array}$ & 5 & 4 & 5 & 5 & 5 & 5 & 5 & 5 & 5 & 5 \\
\hline B5. Navigation & 5 & 4 & 5 & 4 & 5 & 5 & 5 & 5 & 5 & 5 \\
\hline $\begin{array}{l}\text { B6. Goal } \\
\text { Orientation }\end{array}$ & 4 & 3 & 5 & 5 & 5 & 5 & 5 & 5 & 5 & 5 \\
\hline $\begin{array}{l}\text { B7. } \\
\text { Information } \\
\text { Presentation }\end{array}$ & 5 & 4 & 5 & 4 & 5 & 5 & 5 & 5 & 5 & 5 \\
\hline $\begin{array}{l}\text { B8. Media } \\
\text { Integration }\end{array}$ & 4 & 3 & 5 & 4 & 5 & 5 & 5 & 5 & 5 & 5 \\
\hline $\begin{array}{l}\text { B9. Cultural } \\
\text { Sensitivity }\end{array}$ & 3 & 3 & 4 & 3 & 4 & 4 & 4 & 3 & 4 & 4 \\
\hline $\begin{array}{l}\text { Pearson } \\
\text { Correlation } \\
\text { Coefficient }\end{array}$ & \multicolumn{2}{|c|}{$\begin{array}{l}0.58 \\
\text { Moderate } \\
\text { Correlation }\end{array}$} & \multicolumn{2}{|c|}{$\begin{array}{l}0.60 \\
\text { Moderate } \\
\text { Correlation }\end{array}$} & \multicolumn{2}{|c|}{$\begin{array}{l}0.93 \\
\text { Very high } \\
\text { positive } \\
\text { correlation }\end{array}$} & \multicolumn{2}{|c|}{$\begin{array}{l}0.93 \\
\text { Very high } \\
\text { positive } \\
\text { correlation } \\
\end{array}$} & \multicolumn{2}{|c|}{$\begin{array}{l}0.94 \\
\text { Very high } \\
\text { positive } \\
\text { correlation }\end{array}$} \\
\hline
\end{tabular}




\begin{tabular}{|c|c|c|c|c|c|c|c|c|c|c|}
\hline Dimension & \multicolumn{2}{|c|}{$\begin{array}{c}\text { Elevator } \\
\text { Up }\end{array}$} & \multicolumn{2}{|c|}{$\begin{array}{c}\text { Inclusion } \\
\text { Bridges }\end{array}$} & \multicolumn{2}{|c|}{ Stereowiped } & \multicolumn{2}{|c|}{$\begin{array}{c}\text { Collins Big } \\
\text { Cat }\end{array}$} & \multicolumn{2}{|c|}{$\begin{array}{c}\text { Sleepover in } \\
\text { Antarctica }\end{array}$} \\
\hline $\begin{array}{l}\text { B1. Ability to } \\
\text { Save } \\
\text { Progress }\end{array}$ & 1 & 1 & 5 & 1 & 5 & 2 & 5 & 1 & 5 & 4 \\
\hline B2. Integration & 2 & 1 & 2 & 1 & 3 & 1 & 3 & 1 & 2 & 1 \\
\hline $\begin{array}{l}\text { B3. Screen } \\
\text { Design }\end{array}$ & 5 & 5 & 5 & 5 & 5 & 5 & 5 & 5 & 5 & 5 \\
\hline $\begin{array}{l}\text { B4. Ease of } \\
\text { Use }\end{array}$ & 5 & 5 & 2 & 5 & 5 & 5 & 5 & 4 & 5 & 5 \\
\hline B5.Navigation & 5 & 5 & 5 & 5 & 5 & 5 & 5 & 5 & 5 & 5 \\
\hline $\begin{array}{l}\text { B6. Goal } \\
\text { Orientation }\end{array}$ & 5 & 5 & 3 & 5 & 5 & 5 & 5 & 5 & 5 & 5 \\
\hline $\begin{array}{l}\text { B7.Information } \\
\text { Presentation }\end{array}$ & 5 & 5 & 5 & 5 & 5 & 5 & 5 & 5 & 5 & 5 \\
\hline $\begin{array}{l}\text { B8. Media } \\
\text { Integration }\end{array}$ & 5 & 5 & 5 & 5 & 5 & 5 & 5 & 5 & 5 & 5 \\
\hline $\begin{array}{l}\text { B9. Cultural } \\
\text { Sensitivity }\end{array}$ & 3 & 3 & 4 & 3 & 4 & 3 & 3 & 3 & 3 & 4 \\
\hline $\begin{array}{l}\text { Pearson } \\
\text { Correlation } \\
\text { Coefficient }\end{array}$ & \multicolumn{2}{|c|}{$\begin{array}{l}0.98 \\
\text { Very high } \\
\text { positive } \\
\text { correlation }\end{array}$} & \multicolumn{2}{|c|}{$\begin{array}{l}0.21 \\
\text { Negligible } \\
\text { correlation }\end{array}$} & \multicolumn{2}{|c|}{$\begin{array}{l}0.78 \\
\text { High positive } \\
\text { correlation }\end{array}$} & \multicolumn{2}{|c|}{$\begin{array}{l}0.58 \\
\text { Moderate } \\
\text { Correlation }\end{array}$} & \multicolumn{2}{|c|}{$\begin{array}{l}0.89 \\
\text { High positive } \\
\text { correlation }\end{array}$} \\
\hline
\end{tabular}

\begin{tabular}{|l|c|c|c|c|c|c|c|c|c|}
\hline \multicolumn{1}{|c|}{ Dimension } & \multicolumn{2}{|c|}{$\begin{array}{c}\text { Sleepover } \\
\text { in Africa }\end{array}$} & \multicolumn{2}{|c|}{$\begin{array}{c}\text { Everyday } \\
\text { Racism }\end{array}$} & \multicolumn{2}{|c|}{ Switch Fan } & \multicolumn{2}{c|}{$\begin{array}{c}\text { Sensory } \\
\text { Room }\end{array}$} & $\begin{array}{c}\text { Mean Score by } \\
\text { Dimension }\end{array}$ \\
\hline $\begin{array}{l}\text { B1. Ability to } \\
\text { Save } \\
\text { Progress }\end{array}$ & 5 & 4 & 5 & 3 & 1 & 1 & 1 & 1 & 3.28 \\
\hline $\begin{array}{l}\text { B2. } \\
\text { Integration }\end{array}$ & 2 & 1 & 3 & 3 & 3 & 1 & 3 & 1 & 1.82 \\
\hline $\begin{array}{l}\text { B3. Screen } \\
\text { Design }\end{array}$ & 5 & 5 & 5 & 5 & 5 & 5 & 5 & 5 & 4.78 \\
\hline $\begin{array}{l}\text { B4. Ease of } \\
\text { Use }\end{array}$ & 5 & 5 & 4 & 4 & 5 & 5 & 5 & 5 & 4.75 \\
\hline $\begin{array}{l}\text { B5. } \\
\text { Navigation }\end{array}$ & 5 & 5 & 4 & 4 & 5 & 5 & 5 & 5 & 4.86 \\
\hline $\begin{array}{l}\text { B6. Goal } \\
\text { Orientation }\end{array}$ & 5 & 5 & 5 & 5 & 5 & 5 & 5 & 5 & 4.82 \\
\hline $\begin{array}{l}\text { B7. } \\
\text { Information } \\
\text { Presentation }\end{array}$ & 5 & 5 & 5 & 5 & 5 & 5 & 5 & 5 & 4.92 \\
\hline $\begin{array}{l}\text { B8. Media } \\
\text { Integration }\end{array}$ & 5 & 5 & 5 & 5 & 5 & 5 & 5 & 5 & 4.86 \\
\hline $\begin{array}{l}\text { B9. Cultural } \\
\text { Sensitivity }\end{array}$ & 4 & 4 & 5 & 4 & 3 & 3 & 3 & 3 & 3.5 \\
\hline $\begin{array}{l}\text { Pearson } \\
\text { Correlation } \\
\text { Coefficient }\end{array}$ & $\begin{array}{l}0.96 \\
\text { Very high } \\
\text { positive } \\
\text { correlation }\end{array}$ & $\begin{array}{l}\text { Moderate } \\
\text { positive } \\
\text { correlation }\end{array}$ & $\begin{array}{l}0.53 \\
\text { Very high } \\
\text { positive } \\
\text { correlation }\end{array}$ & $\begin{array}{l}\text { Very high } \\
\text { positive } \\
\text { correlation }\end{array}$ & \\
\hline
\end{tabular}

